\title{
Fibrinonecrotic enteritis of piglets in a commercial farm: a postmortem study of the prevalence and the role of lesion associated agents Isospora suis and Clostridium perfringens ${ }^{1}$
}

\author{
Macarena G. Sanz ${ }^{2}$, Lucila Venturini ${ }^{3}$, Ronnie A. Assis ${ }^{4}$, Francisco Uzal ${ }^{5}$, Miguel A. \\ Risso $^{6}$, Julio R. Idiart ${ }^{6}$ and Carlos J. Perfumo ${ }^{6 *}$
}

\begin{abstract}
Sanz M.G., Venturini L., Assis R.A., Uzal F., Risso M.A., Idiart J.R. \& Perfumo C.J. 2007. Fibrinonecrotic enteritis of piglets in a commercial farm: a postmortem study of the prevalence and the role of lesion associated agents Isospora suis and Clostridium perfringens. Pesquisa Veterinária Brasileira 27(7):297-300. Facultad de Ciencias Veterinarias, Universidad Nacional de La Plata, CC 296, B1900 AVW, 60 y 119, La Plata, Argentina. E-mail: cjperfumo@fcv.unlp.edu.ar

The objectives were to determine the prevalence of fibrinonecrotic enteritis (FNE) on a farrow-to-finish farm of 1,000 sows, to categorize the pathological changes, and to to investigate the lesion associated agents Isospora suis and Clostridium perfringens. Causes of preweaning mortality (PWM) were classified into 8 categories including FNE. Obtained data were evaluated for statistical significance by adjusted Chi-square analysis. Samples of FNE were taken for complementary studies including a PCR technique for genotyping toxin genes of Clostridium perfringens from gut samples fixed in $10 \%$ neutral formalin. From 3,153 piglets examined, less than $1 \%$ was classified as FNE. FNE prevalence increased progressively from the first to the third week, the last differing statistically from the others. Eighty percent of gut samples with FNE lesions were positive to Isospora suis, when examined by PCR from 9 severe FNE lesions detected 7 positive samples only for $\alpha$ toxin gene, characteristic of $C$. perfringens type-A.
\end{abstract}

INDEX TERMS: Fibrinonecrotic enteritis, piglets, prevalence, Isospora suis, Clostridium perfringens, PCR.

RESUMO.- [Enterite fibrinonecrótica em leitões de uma granja comercial: estudo pós-morte da prevalência e associação da lesão com Isospora suis e Clostridium perfringens.] Os objetivos deste trabalho foram determinar a prevalência de enterite fibrinonecrótica (EFN) em uma granja tecnificada

\footnotetext{
${ }^{1}$ Received on February 2, 2007.

Accepted for publication on March 15, 2007.

${ }^{2}$ College of Veterinary Medicine, P.O. Box 647010, Washington State University, Pullman, WA 99164-7010, USA.

${ }^{3}$ Cátedra de Parasitología y Enfermedades Parasitarias, Facultad de Ciencias Veterinarias, Universidad Nacional de La Plata, CC 296, B 1900 AVW, 60 y 119, La Plata, Argentina.

${ }^{4}$ Laboratorio de Clostridioses, LARA-MG, Ministério da Agricultura, Pecuária e Abastecimento, Av. Rômulo Joviano s/n, Pedro Leopoldo, MG, Brazil.

${ }^{5}$ California Animal Health and Food Safety Laboratory System, School of Veterinary Medicine, University of California, Davis, 105 W Central Ave., San Bernardino, CA 92408, USA.

${ }^{6}$ Cátedra de Patología Especial, Facultad de Ciencias Veterinarias, Universidad Nacional de La Plata, CC 296, B 1900 AVW, 60 y 119, La Plata, Argentina. "Corresponding author: cjperfumo@fcv.unlp.edu.ar
}

com 1000 matrizes, classificar as mudanças patológicas e investigar a lesão decorrente da associação dos agentes Clostridium perfringens e Isospora suis. As lesões macroscópicas devidas à mortalidade pré-desmame (MPD) foram classificadas em oito categorias incluindo EFN. Os dados obtidos foram avaliados pelo teste Qui-quadrado. Amostras de EFN foram colhidas para estudos complementares incluindo uma técnica de reação em cadeia da polimerase (PCR) para identificação dos genes codificadores de toxinas de $C$. perfringens a partir de amostras do intestino fixadas em formalina a 10\%. Dos 3.153 leitões examinados, menos que $1 \%$ foram classificados como EFN. As análises estatísticas revelaram que a EFN aumentou progressivamente a partir da primeira para a terceira semana, sendo que a última semana diferiu estatisticamente das demais. Oitenta porcento das amostras do intestino com EFN foram positivas para I. suis. Por meio da PCR a partir dos 9 casos de EFN severa, 7 foram positivos somente para o gene da toxina alfa, característico de $C$. perfringens tipo A.

TERMOS DE INDEXAÇÃO: Enterite fibrinonecrótica, leitões, prevalência, Isospora suis, Clostridium perfringens, PCR. 


\section{INTRODUCTION}

Fibrinonecrotic enteritis (FNE) is a pathological condition sporadically found in piglets died at the pre and postweaning periods. Grossly, it is characterized by a rigidity of the jejunum and ileum due to a thickening of the mucosa by a fibrinonecrotic membrane. Microscopically, superficial (involving villous cells) or deep (affecting cryptal cells), coagulative necrosis is seen with focal areas of fibrinonecrotic exudates (Eustis \& Nelson 1981, Perfumo et al. 1998). Although there is no doubt about the definition of the gross lesions, from the etiological point of view, several microorganisms, alone or in association, have been reported to be involved in the pathogenesis of FNE. Less than $20 \%$ of heavy Isospora suis infected piglets (200,000 or more oocysts) have showed fibrinonecrotic lesions (Lindsay \& Blagburn 1994). A field study reported that Isospora suis can be identified in $50 \%$ of grossly fibrinonecrotic samples (Perfumo et al. 1998). Besides, I. suis infection can help to express or increase the severity of rotavirus infection. Clinical signs and necrotic lesions are more severe when both agents are concurrently infecting the small intestine, because the enterocytes on the central and distal portions of the villi are the target cells for both pathogens (Lindsay et al. 1999).

Necrotic hemorrhagic lesions are also found in less than one week old non-immune piglets associated with heavy infection of Clostridium perfringens type-C (Songer \& Glock 1998, Taylor 1999). In subacute cases the wall of the small intestine is thickened and the mucosa is covered by a tightly adherent necrotic membrane (Songer \& Glock 1998, Songer \& Trigo 1998). However, one report showed that $95 \%$ of the strains of $C$. perfringens isolated from piglets with FNE and suspected to be produced by type-C, were type-A strains (Songer \& Glock 1998). The above information implies that there is some controversial information about the etiology and pathogenesis of FNE and probably it tends to remain unclarified if field studies about prevalence and associated agents are not undertaken.

The aims of this work were to determine the prevalence of FNE in routine postmortem examined piglets on a farrowto-finish farm of 1,000 sows, further to categorize the pathological changes and finally to investigate the lesion associated agents such as Isospora suis and Clostridium perfringens.

\section{MATERIALS AND METHODS}

General aspects. The study was performed between January 1999 and July 2000 on a farrow-to-finish farm of 1,000 sows. The farm was considered as free from PRRS, Aujeszky and TGE virus by serology. Attempts to control Escherichia coli diarrhoea were made by the sows' vaccination twice at 30 and 15 days before farrowing. Five farrowing houses with all in-all out flow system kept piglets from farrowing to weaning at 21 days. The study comprised visits at weekly intervals and necropsy of all dead and kept refrigerated piglets. Suspected causes of death were registered at the farrowing house by trained personnel on a farrowing sheet, and confirmatory diagnosis was performed by an abbreviated necropsy procedure (Sanz et al. 2001). Causes of preweaning mortality (PWM) were categorised as follows: 1) underweight ( new born piglets weighted less than $800 \mathrm{~g}$ ), 2) low-viability/starvation (piglets weighted more than 800 $\mathrm{g}$, but still looked small and without milk in stomach), 3) diarrhoea (dehydrated piglets with distended and congestive small intestine with alkaline $\mathrm{pH}$ content), 4) malformations, 5) trauma (oedema and haemorrhages in subcutaneous tissues or in visceral organs), 6) miscellaneous (grossly changes not comprised in other categories such as tumour), 7) infections (any grossly seen exudates found in body) and 8) fibrinonecrotic enteritis (FNE).

Statistical analysis. Obtained data were registered on a calculation sheet and evaluated for monthly and weekly statistical significance by adjusted Chi-square analysis.

Histopathological study. From freshly grossly FNE cases, at least two samples of jejunum and ileum were taken for histopathological studies (Haematoxylin-Eosin and Gram stains). FNE samples were microscopically scored in: slight (superficial necrosis of the mucosa with detectable I. suis stages), moderate (necrosis of the mucosa and submucosa) and severe (deep coagulative necrosis involving mucosa, submucosa and muscle layers).

Complementary studies. From all cases of FNE, parasitological (Sheathers sugar solution), bacteriological (E. coli isolation) and virological (negative-staining electron microscopy) studies were carried out. A PCR technique for genotyping $\alpha, \beta, \varepsilon$ and, $\imath$ toxin of Clostridium perfringens was performed from 9 severe scored cases of FNE gut lesions fixed in 10\% neutral buffered formalin, according with the procedure described by Warren et al. (1999).

\section{RESULTS}

Statistical analysis. In total, 3,153 piglets were postmortem examined, with 24 cases classified as FNE (Fig.1). Graded score lesions found among the 24 cases recorded were: 3 slight, 4 moderate and 17 severe. In the later, inflammation involved the submucosa and the muscle layers with neutrophils and macrophages dividing normal from affected areas (Fig.2).The overall survey of PWM categories were sorted into 8 statistically different groups $(\mathrm{p}<0.0001)$ (Fig.3); among them, FNE comprised $0.76 \%$. Percentages of piglets dying at the first, second and third weeks of life were $41.32 \%, 39.11 \%$ and $19.57 \%$ respectively. Further weekly intervals analysis of PWM categories (diarrhoea and FNE) against the final figures showed the following pattern: a) diarrhoea percentages found

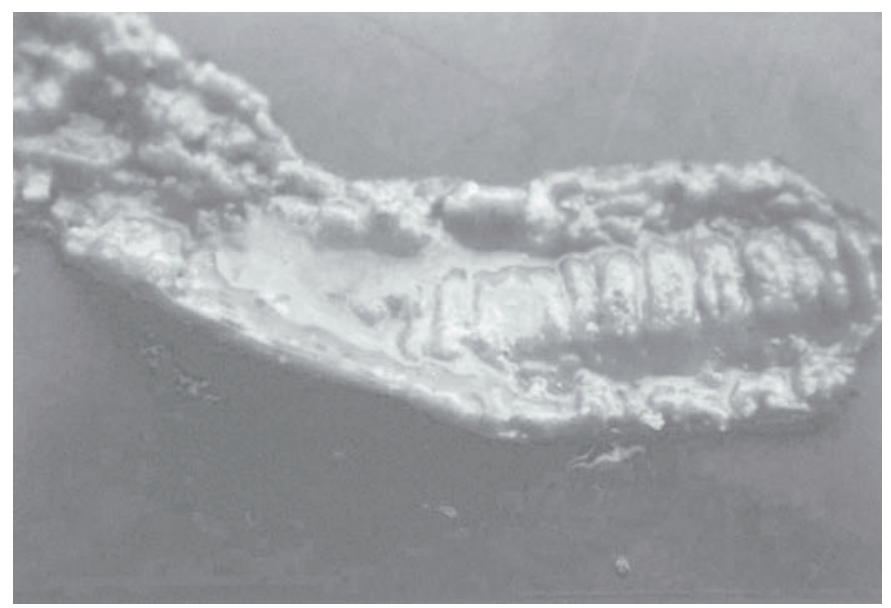

Fig.1. Gross appeareance of ileum with fibronecrotic enteritis (FNE) lesion. 


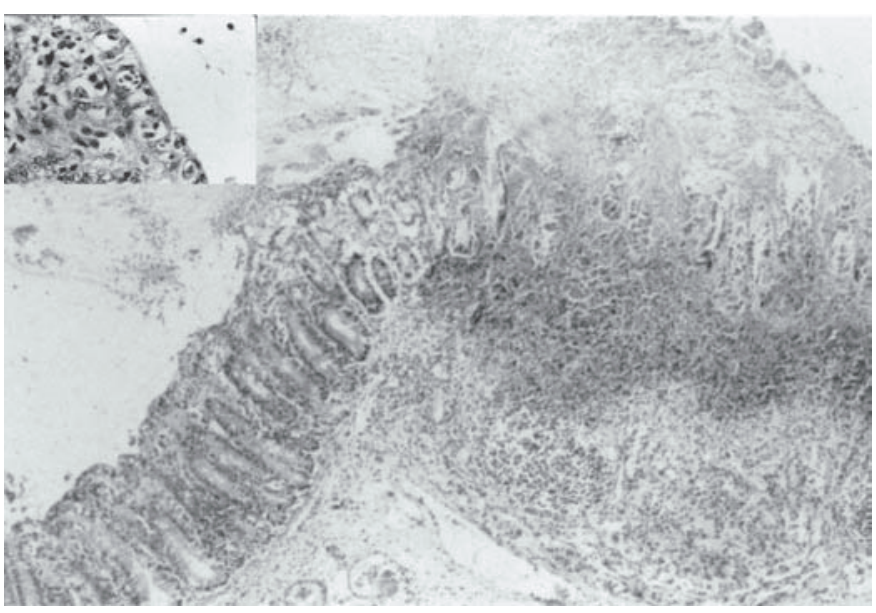

Fig.2. Coagulative necrosis involving the mucosa, submucosa and the muscle with focal areas of fibronecrotic exudates in the ileum of a piglet infected with Isospora suis and Clostridium perfringens type-A. At left corner, high magnitude of the remained epithelia with heavy infection with I. suis stages. HE, obj.10 and 100 , respectively.

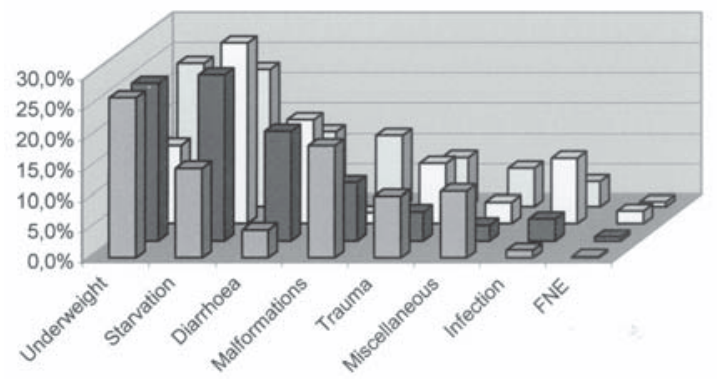

口Week 1

aWeek 2

口Week 3

口Total \%

Fig.3. Preweaning mortality (PWM) category percentages of the overall survey.

Table 1. Statistical significance of diarrhoea and FNE groups of PWM categories dying at first, second and third weeks of life in comparison with the final figures

\begin{tabular}{ccccc}
\hline $\begin{array}{c}\text { PWM } \\
\text { categories }\end{array}$ & $\begin{array}{c}\text { \% dead at } \\
1^{\text {st }} \text { week }^{*}\end{array}$ & $\begin{array}{c}\text { \% dead at } \\
2^{\text {nd }} \text { week }\end{array}$ & $\begin{array}{c}\text { \%dead at } \\
3^{\text {rd }} \text { week }\end{array}$ & \% Final \\
\hline Diarrhoea & $4.60^{\text {a a }}$ & $17.92^{\text {a b }}$ & $17.02^{\text {a b }}$ & $12.24^{\text {a c }}$ \\
FNE & $0.23^{\text {b a }}$ & $0.65^{\text {b a }}$ & $2.11^{\text {b b }}$ & $0.76^{\text {b c }}$
\end{tabular}

*Numerical data not sharing the same letter in same column are significantly different $(\mathrm{P}<0.0001)$. Numerical data not sharing the same bold letter in same line are significantly different $(P<0.0001)$.

at first week was lower and differed significantly from those found at second and third weeks, and b) FNE increased progressively from the first to the third week, the last differed statistically from the others (Table 1).

Complementary studies: By histopathology, in only one moderate FNE lesions Isospora suis stages were identified. Parasitological studies of faeces taken from the farrowing pens along the period revealed $I$. suis in $40 \%$ of samples. Faecal float from gut samples with FNE, revealed $80 \%$ positive to $I$. suis. Non-haemolytic E. coli was isolated, almost in pure culture, from 6 cases; however no further studies of virulence markers were carried-out. Negative-staining electron micro-

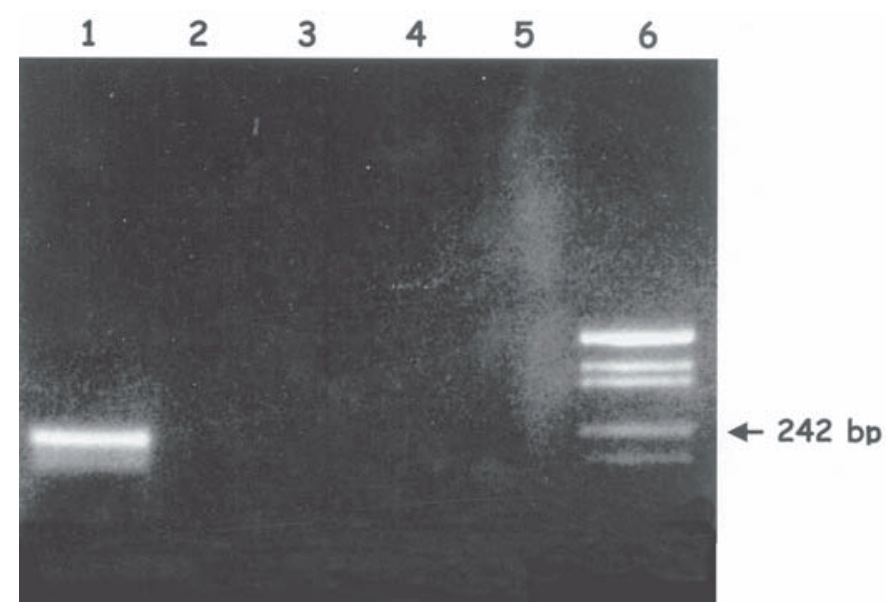

Fig.4. Agarose gel electrophoresis of PCR amplicons obtained using formalin-fixed paraffin imbedded ileum tissues from a piglet with fibronecrotic enteritis (FNE), using sets of primers specific for alpha (lane 1), beta (lane 2), epsilon (lane 3) and iota (lane 4) toxin genes, and with no primers added (negative control, lane 5). Lane 6: molecular weight marker.

scopy studies carried-out from only 50\% of severe FNE cases were negative for virus particles. PCR technique results for Clostridium perfringens toxins $\alpha, \beta, \varepsilon$ and $\mathrm{\imath}$ from 9 severe cases of FNE showed 7 positive samples only for $\alpha$ toxin gene, characteristic of $C$. perfringens type-A (Fig.4).

\section{DISCUSSION}

In our study of PWM, diarrhoea category found at second and third weeks was mainly due to Isospora suis infection. From epidemiological point of view, the age of the affected piglets (from 5 days to weaning with a peak at 14 days), the consistency and colour of the faeces (mayonnaise and sheep pellet like) and the poor antibiotic response were the most remarkable characteristics (Lindsay \& Blagburn 1994, Perfumo et al. 1998, Lindsay et al. 1999). Faecal sampling or scraping of gut mucosa studies allowed to identify the agent. However total percentage of FNE lesions suspected to be associated with I. suis was lower in comparison with others PWM categories and even with those of a previous report (Eustis \& Nelson 1981). In field outbreaks of coccidiosis, gross fibrinonecrotic lesions are usually seen in less than $20 \%$ of the cases (Lindsay \& Blagburn 1994). Experimental studies found a diphtheric membrane in jejunum and ileum in one day old piglets receiving 200,000 ( $22 \%$ with FNE) to 400,000 oocysts (53\% with FNE) while no gross lesions was seen in older pigs even with higher dosis (Stuart et al. 1982). In the later, histopathological studies have shown segmental villous atrophy characterized by a slight to severe reduction of the height of the villi with flattened tips epithelial cells infected with asexual stages type 1 merozoites and rarely type 2 merontes (Eustis \& Nelson 1981, Stuart et al. 1982, Lindsay \& Blagburn 1994, Perfumo et al. 1998, Lindsay et al. 1999), however neither coagulative necrosis of the mucosa nor inflammatory changes in the submucosa and muscle layers were reported. In a previous study, severe cases with not 
remnant enterocytes, only colonies or single rod-shaped Gram positive bacteria within the fibrinonecrotic material were identified (Perfumo et al. 1998). In the current study even in slight graded FNE lesion no I. suis stages were seen because the sloughed of the tips epithelial cells. In those cases diagnoses of coccidiosis was based only on the demonstration of oocysts in faeces.

In 1 to 2-day-old piglets, Clostridium perfringens type-C infections produce peracute disease with high morbidity (30$50 \%$ ), and mortality (50-100\%) (Songer \& Glock 1998, Songer \& Trigo 1998). Clinical signs and lesions are related with bloody necrotic diarrhoea and enteritis (Songer \& Glock 1998, Songer \& Trigo 1998) neither of them were seen in our study. In subacute clinical cases, diarrhoea and necrotic lesions resembling those seen in severe FNE were reported (Songer \& Trigo 1998). The detection in severe FNE lesions of a but not $\beta$ toxin gene suggests that $C$. perfringens type- $A$ and not type- $C$ might be associated with those lesions. This hypothesis is supported by the fact that most of the $C$. perfringens strains isolated from field cases of necrotic enteritis and suspected to be type- $C$ were type A (Songer \& Glock 1998). However C. perfringens type-A is a normal inhabitant of the digestive tract of pigs (Songer \& Glock 1998, Songer \& Trigo 1998, Taylor 1999) and it involvement as responsible for necrotic lesions seems to be analyzed through experimental studies. If FNE is produced or facilitated by the action of a toxin on the intestinal mucosa, the diagnosis of this condition should be based upon demonstration of the mentioned toxin in the intestine. However, detection of $\alpha$ toxin in biological samples is difficult because the toxin is very labile and bacterial or tissue enzymes readily degrade it. However PCR technique applied on formalin fixed tissue provides a useful tool to generate information related to the role of $C$. perfringens in the pathogenesis of FNE. According to a previous study (Eustis \& Nelson 1981) necrotic lesion in piglets might be produced by bacterial invasion of the villous lamina propria at foci of denuded epithelium caused by $I$. suis which should favour the action of $\alpha$ toxin produced by $C$. perfringens type-A. Further $\alpha$ toxin, a phospholipase acting on membranes of erythrocytes, platelets, leukocytes, endothelial and muscle cells, might produce villous oedema, epithelial, vascular and muscular damage (Songer \& Glock 1998, Songer \& Trigo 1998) as was seen in our study in severe FNE lesions.

In conclusion, weekly post-mortem survey of PWM showed that FNE percentage was less than $1 \%$ and prevalence increased progressively from the first to the third week of age. Both $I$. suis and $C$. perfringens type-A were found associated with FNE lesions as was demonstrated by a combination of histopathological, parasitological and PCR procedures.

\section{REFERENCES}

Eustis S.L. \& Nelson D.T. 1981. Lesions associated with coccidiosis in nursing piglets. Vet. Pathol. 18:21-28.

Lindsay D.S. \& Blagburn B.L. 1994. Biology of mammalian Isospora. Parasitol. Today 10:214-219.

Lindsay D.S., Blagburn B.L. \& Dubey J.P. 1999. Coccidia and other protozoa, p.655-667. In: Straw B.E., D'Allaire, S., Mengeling W.L. \& Taylor D. (ed.), Diseases of Swine. $8^{\text {th }}$ ed. Iowa State University Press, Ames, Iowa.

Perfumo C.J., Venturini L., Sanguinetti H.R., Aguirre J.I., Armocida A.D., Petruccelli M.A. \& Moredo F. 1998. Infección por Isospora suis sola o asociada a virus entéricos como causa de alta morbimortalidad en lechones lactantes. Revta Med. Vet., Buenos Aires, 79:264-268.

Sanz M.G., Sernia C., Bustos L., Sanguinetti H.R., Risso M.A., Venturini L., Idiart J.R. \& Perfumo C.J. 2001. Why should piglets dead at the pre-weaning period be post-mortem examined and statistically analysed at weekly intervals? Proc. $32^{\text {nd }}$ Annu. Meet. Am. Assoc. Swine Vet. (AASV), Nashville, Tennessee, p.69-74.

Songer J.G. \& Glock R.D. 1998. Enteric infection of swine with Clostridium perfringens types A and C. SHAP 6:223-226.

Songer G.J. \& Trigo A.M. 1998. Enteric infection of swine with Clostridium perfringens types A and C. Proc. $2^{\text {th }}$ Annu. Meet. Am. Assoc. Swine Vet. (AASV), Des Moines, Iowa, p.459-464.

Stuart B.P., Gosser H.S., Allen C.B. \& Bedell D.M. 1982. Coccidiosis in swine: dose and age response to Isospora suis. Can. J. Comp. Med. 46:317-320.

Taylor D.J. 1999. Clostridial infections, p.395-412. In: Straw B.E. D'Allaire S., Mengeling W.L. \& Taylor D. (ed.), Diseases of Swine. $8^{\text {th }}$ ed. Iowa State University Press, Ames, Iowa.

Warren A.L., Uzal F.L., Blackall L.L. \& Kelly W.R. 1999. PCR detection of Clostridium perfringens type $\mathrm{D}$ in formalin-fixed, paraffin-embedded tissues of goats and sheep. Lett. Appl. Microbiol. 29:15-19. 